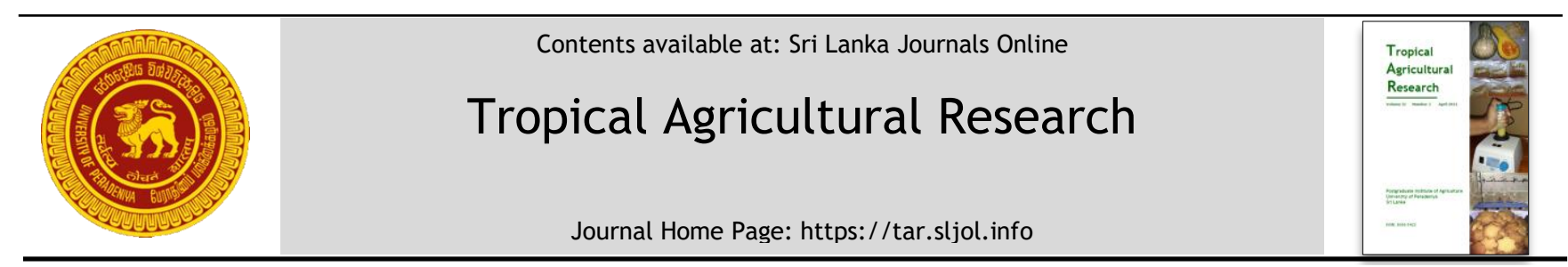

\title{
Developing an Assessment Frame for Tea Sector Farmer Organizations Based on Opinions of Agriculture Extension Personnel
}

\author{
K.G.J.P. Mahindapala ${ }^{1} 2^{*}$, M.W.A.P. Jayathilaka ${ }^{1}$, L.N.A.C. Jayawardana ${ }^{3}$ and T. Sivananthawerl ${ }^{4}$ \\ ${ }_{1}^{1}$ Postgraduate Institute of Agriculture, University of Peradeniya, Sri Lanka. \\ ${ }^{2}$ Tea Research Institute of Sri Lanka, Ratnapura, Sri Lanka. \\ ${ }^{3}$ Department of Agriculture Extension, Faculty of Agriculture, University of Peradeniya, Sri Lanka. \\ ${ }^{4}$ Department of Crop Science, Faculty of Agriculture, University of Peradeniya, Sri Lanka.
}

\section{ARTICLE INFO}

\section{Article history:}

Received: 15 August 2020

Revised version received: 6 October 2020

Accepted: 8 January 2021

Available online: 1 April 2021

\section{Keywords:}

Extension Officers

Factor analysis

Opinion survey

Tea Smallholding Development Society

\section{Citation:}

Mahindapala, K.G.J.P., Jayathilaka, M.W.A.P., Jayawardana, L.N.A.C., and Sivananthawerl, T. (2021). Developing an Assessment Frame for Tea Sector Farmer Organizations Based on Opinions of Agriculture Extension Personnel. Tropical Agricultural Research, 32(2): 135-145.

DOI: http://doi.org/10.4038/tar.v32i2.8461

Mahindapala, K. G. J. P.

https://orcid.org/0000-0002-5466-4123

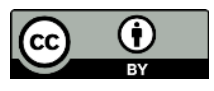

\section{ABSTRACT}

Farmer based, Tea Smallholding Development Societies (TSDSs) were established to address resource limitation problems faced by individual farmers. Well established Farmer Based Organizations (FBOs) provide many services to the members, including the supply of inputs, capacity building, extension, processing and marketing, financial services, welfare and business activities. This study attempted to understand the relative importance of these tasks of the TSDSs. An opinion survey was conducted, using a self-administered structured questionnaire, with two groups of respondents, who were requested to give a rating for a set of functions. These two groups consisted of working extension officials (EO) and extension experts having close interactions with the tea sector. Results revealed that a majority of the extension officials prefer TSDS to be focused on need identification, extension activities and dealing with inputs and resources. The EOs affiliated to the two main extension organizations had similar opinion on the functions. The Chi-square test confirmed that the socio-personal factors did not differ in the two groups. In contrast with the opinion of the EOs, the Experts group expect the TSDS to be more committed to marketing related activities. This was in line with the ground situation of the success FBOs in the region. However, the Expert group has not undermined the importance of the three tasks that EOs valued. For-profit activities have received fairly good rating from the Experts than that of the other category. Other functions received a low rating by both parties except welfare activity which was slightly favoured by EOs. Based on the factor analysis, it appears that some of these dimensions may be grouped into two components, such as economic-oriented and service-oriented. This information on relative importance could be used in assessing the TSDS.

*Corresponding author : prasanjithjm@gmail.com 


\section{INTRODUCTION}

Low capital and inadequacy of other resources are common problems faced by smallholder farmers. Thus, production is limited to low quantities and cannot generate attractive profits. Lack of market access, low bargaining power, lack of knowledge on agricultural technologies and poor infrastructure facilities also greatly influence the productivity of smallholder farmers. Farmer Based organisations (FBOs) were formed to resolve the above issues through a collective approach. (Barham and Chitemi, 2009). Individuals, by interacting with each other and establishing networks can achieve relatively higher benefits than working individually (Ostrome, 2000). These interpersonal networks are considered as social capital (Dasgupta, 2002). Therefore, FBO can be understood as a structured arrangement made to acquire social capital., It is an entity that represents the farmers in a given geographical area and mainly deals with agriculture enterprise-related needs of the members (Esham, 2012). Usually, a FBO has well-defined membership, and their principal function is to provide the service to the members (Stockbridge et al., 2003). A FBO has an organised structure, a purpose for gathering and attempt to achieve a standard set of objectives. It is an essential entity to empower the rural farmers, poverty alleviation and eventually uplift their living standards. According to Penrose-Buckley (2007), there are three features of a FBO: (i) It mostly engages in rural business, (ii) comprises of producers who have ownership and have control over their business (iii) the membership collectively acts on the market-related matters.

FAO defines the FBO as: "A formal voluntary membership organisation created for the economic benefit of farmers to provide them with services that support their farming activities such as bargaining with customers; collecting market information; accessing inputs, services and credit; providing technical assistance; and processing and marketing farm products. Formal membership criteria could include payment of membership fees or a percentage of farmers' production. Informal membership criteria could be based on ethnicity or gender" (Kassam et al., 2011). It is noteworthy that this definition recognises the importance of value addition of the primary agricultural produce of the farmers and marketing them through the agribusiness approach.

Chamala and Shingi (1997) divided the FBOs into two groups as community-based with resources oriented and, commodity-based with marketoriented. First type mainly deals with inputs and other resource needs of the members. The second group is specialised in a specific commodity and more concerned with value addition and selling their products in the competitive markets.

Scaling of economies, reduction of transaction and coordination costs, accessing capital, risk management and building up of countervailing power are some of the economic expectations of formation of FBO. (Spileman and Bernard, 2009; Datta, 2004; Sallokhe, 2016). In that context, Successful FBOs undertakes multiple tasks/functions which are shown in Table 1.

Moreover, some studies revealed that, availability of some of the above services (Table 1) within the FBOs have an impact on the affiliation of the members to the FBO. (Matchaya, 2010; Assante et al., 2011). Farmer Producer Organisation (FPO) or cooperative societies In India, had been struggling due to poor governance, lack of accountability, financial constraints, and the problem of social loafing. (Borshtoem,2013; Datta,2004). However, by the introduction of some reforms, some of them were transformed as Farmer Producer Companies (FPCs). It was reported that these FPCs operate as successful entities, because of adoption of some of the above activities mentioned in Table 1 (Sharma, 2007; Terribin and Hassler 2012; Terribian, 2014). The Japanese Agriculture Cooperatives also handle most of the above activities, and they are considered as one of the successful FOs in the world (Rajarathna, 2007; Kazuhito, 2013).

By amending of a legislative Acts, (No. 36 of 1991 and No. 21 of 1997) Tea Smallholding Development Societies (TSDS) were established in the tea sector in Sri Lanka to achieve the following objectives: (i) To develop tea smallholdings (ii) Provide the marketing facilities for growers (iii) To promote the economic and welfare activities (iv) Facilitate the members in the area to obtain credits and inputs and, (v) Engage in development projects in the area. Tea Smallholdings Development Authority (TSHDA) is the principal service providing agency for tea smallholders and TSDS.

However, Bandula et al. (2016), reported that there is no significant improvement in tea smallholding sector in Matara district attributable to the TSDSs. Further, Mahindapala et al. (2020a) also reported that the majority of the tea smallholding societies are not performing well due to several internal and external factors. Meanwhile, the extents of the different functions (stated in Table 1) offered by the TSDS are not qualitatively or quantitatively evaluated. 
Table 1: Servicers offered by various Farmer Organizations

\begin{tabular}{|c|c|}
\hline Kind of Task & Description \\
\hline Organizing activity & Building capacities, Empowerment, Catalyzing collective actions \\
\hline Production support & Supply of Inputs, Resources, Facilitation through collective activities \\
\hline Marketing services & $\begin{array}{l}\text { Processing, transporting of products, Wearhouse facility, Delivery of } \\
\text { market information, Linking of markets. }\end{array}$ \\
\hline Financial services & Loans and subsidies, promote savings, banking facilities \\
\hline Technology services & Extension, Education, Training, Research activities \\
\hline Welfare & Health, Livelihood support, Child education. \\
\hline Management of resources & Irrigation water, Forest, Soil and Land, Fisheries \\
\hline Policy advocacy & Provides inputs for policy formulation, Act as a pressure group. \\
\hline
\end{tabular}

Adopted from Terebbin and Hassler, 2012; Rondot and Collin, 2007

It is noteworthy to find out which function(s) of TSDS are more important. This understanding will be useful to rationally evaluate the particular rural societies. If there is a gap between the expected tasks and actual activities, that could be the reason for the poor output of these FOs.

Hence, this study attempted to determine the relative importance of the various tasks that could be pursued by the farmer-based, successful Tea Smallholding Development Societies and develop a suitable measurement Framework to be used in assessing the rural level TSDSs

\section{METHODOLOGY}

Based on the literature survey and the outcome of the past research work (Mahindapala et al., 2020a, Mahindapala et al., 2020b, unpublished data of Author), following dimensions (Table 2) were identified and hypothetically assumed that they express the efficacy of rural TSDSs.

The respondents were asked to rank and assign weightages for each dimension based on their relative importance to the TSDS in such a way that total weightages would be equal to 100 . In developing the assessment frame, it is assumed, the overall efficacy level of TSDS can be expressed through the level of engagement in these factors/functions.

To estimate the relative importance of each dimension, they were included in a structured questionnaire, and an opinion survey was conducted. The survey methodology deployed was self-completion questionnaire methodology, which assures respondents to have a fair amount of time to think and provide their responses (Bryman, 2012). The questionnaire was mostly close-ended type and designed in such a way to easily understandable for the respondents. The lower response rate, inability to prompt and, lack of understanding are the major constraints in this type of survey, and certain strategies (ie. explaining and reminding, providing additional information as and when necessary) were adopted to minimise those constraints.

\section{Sampling technique adopted}

Two sampling frames were selected on purposive manner as follows:

1. Extension Officials who closely interacted with TSDS and having practical experiences with them. - This includes extension personal from TSHDA including Tea Inspectors, (TI), Senior Tea Inspectors (STI), Regional Managers and Assistant Regional Managers from all eight major tea growing regions (i.e. Ratnapura, Kegalle, Galle, Matara, Kalutara, Badulla, Kandy and Nuwara Eliya). A total of 85 officers who have minimum more than two years of experience in the profession were selected on purposive manner (Which approximately is $60 \%$ of the sampling frame) for the study. The response rate was $92 \%$. Further, responses from 11 out of 14 extension personnel (having more than three years experience) from Tea Research Institute was also collected.

2. Academics and professionals group included those who have higher academic, research and management background in the field of Extension, Agribusiness management, Farmer Organizations and also those involved in related research disciplines. Under this category, 25 respondents were selected in a purposive manner, and the questionnaire was e-mailed. However, the response rate was comparatively low (72\%) but within an acceptable range (Mangione, 1995). 
Two responses received from TSHDA sampling frame have to be disregarded due to issues related to the reliability and opinions of 76 individuals from TSHDA, 11 from TRI and 18 from the professional category was analysed using descriptive statistics, Nonparametric tests, chisquare test and Factor analysis by using SPSS 16.

\section{RESULTS AND DISCUSSION}

\section{The opinion of the working extension officials (EO)}

\section{Basic characteristics of the Respondent EOs}

About $72 \%$ of the respondents from TSHDA had more than 15 years of experience in the field of extension, while $13 \%$ having more than five years of experience. Furthermore, eighty-four per cent of them have been working at least more than six years with the smallholders. Therefore, it can be assumed that respondents have a reasonable background to formulate and provide the opinion on the focused area. Further, $27 \%$ of them have a bachelor's degree or postgraduate qualifications, while $70 \%$ are Diploma holders. The sample

Table 2: The dimensions/ functions intended to be evaluated

\begin{tabular}{ll}
\hline Dimension & \multicolumn{1}{c}{ Description } \\
\hline Attending to need & How far Tea Smallholding Development Societies able to identify the \\
identification of the & members' extension and other agriculture-related needs. \\
member $\left(\mathrm{X}_{1}\right)$ &
\end{tabular}

Extension Activities $\left(\mathrm{X}_{2}\right)$

F0, help to improve their members' knowledge on agriculture technologies. FO try to solve agricultural related problems. They also facilitate/conduct training programs for members. Motivate members and monitor their agricultural activities.

Welfare activities $\left(\mathrm{X}_{3}\right) \quad$ Farmers join the $\mathrm{FO}$ anticipating various welfare activities. Generally, these facilities include, educational support for members school children, Death donation schemes, Health/Medical support, Recreation activities, Provide some livelihood support etc.

Dealing with various inputs and resources $\left(\mathrm{X}_{4}\right)$

This includes providing of range of inputs (planting materials, fertiliser and Agro-chemicals) to members on credit basis. Availability of physical resources (Eg. Agriculture machinery, Irrigation equipment, Vehicle) for the use of members.

Marketing of products $\left(\mathrm{X}_{5}\right)$ Under this FO Provides a range of facilities such as marketing information, involved in collecting and selling of green leaf tea to the processing centre, Involve in processing/value addition, product diversification and branding and selling of finish product in the high-end market.

Financial support for members $\left(\mathrm{X}_{6}\right)$

Organising/ promoting collective field activities $\left(\mathrm{X}_{7}\right)$

Capacity building. $\left(\mathrm{X}_{8}\right)$ Involvement in nationally important issues $\left(\mathrm{X}_{9}\right)$

Providing credit facilities, sharing of profit/Bonus, coordinating to obtained government subsidies, providing various type of banking service, Providing Insurance service.

Joint activities in the field level may comprise Engage in joint field operation and labour sharing.

This include Conducting capacity building activities for members

Some FOs engage in natural resource management programs Involvement of Environment protection activities, Contribution to policy level issues and Act as a pressure group with respect to a disadvantageous policy decision.

Adherence to administrative and financial procedures $\left(\mathrm{X}_{10}\right)$

Involvement of other Forprofit activities $\left(\mathrm{X}_{11}\right)$

This includes essential routine procedures such as Conducting meetings, as per the constitution, maintaining of accounts, Auditing, Recordkeeping.

FO may involve in other enterprises to generate income to invest in FO activities. 
consisted of $15 \%$ female extension officials, and $15 \%$ were in supervisory grade. When considering the TRI sample, all the respondents are degree holders, and $55 \%$ of them have postgraduate qualifications. About $90 \%$ of them have more than five years of experience in the field of extension and the sector under review.

\section{The ranking pattern of the EOs on the functions}

The frequency analysis of the ranking pattern was summarised in Figure 1, which indicates that 85\% of the respondents have ranked $\mathrm{X}_{1}$ in either $1 \mathrm{st}$, 2nd or 3rd position. Similarly, in the overall assessment, $63 \%$ of the respondents (21\% assigned 1 st place, $36 \%$ 2nd place and $6 \%$ 3rd place) and $46 \%$ of the respondents ( $4 \%$ assigned 1st place, $20 \%$ 2nd place and 22\% 3rd place) have assigned relatively highest rank for $\mathrm{X}_{2}$ (Involvement in Extension) and $\mathrm{X}_{4}$ (Inputs and Resource dealing) dimensions respectively. On the other hand, $X_{9}$ (Involvement in National Issues) and $\mathrm{X}_{11}$ (Involvement in for-profit activities) dimensions were rated at the lowest positions by the respondents. The dimensions such as $\mathrm{X}_{5}, \mathrm{X}_{6}, \mathrm{X}_{7}, \mathrm{X}_{8}$ and $\mathrm{X}_{10}$ were neither ranked in the highest position and nor in the lowest position and placed in a moderate rank (either of $4,5,6,7$, and 8 ) by the majority (more than $50 \%$ ) of the respondents.

In addition to the ranking of the dimensions, respondents were also asked to provide a weightage on the dimensions and Friedman test was performed to see the differences between their choices with respect to dimensions and test statistics revealed that there is a significant difference existed (chi-square value for weightages 423.4 at $\mathrm{p}<0.001, \mathrm{df}=10$ ) The mean rank values of the Friedman test is given in Table 3.

Accordingly, $\mathrm{X}_{1}, \mathrm{X}_{2}, \mathrm{X}_{4}$, and $\mathrm{X}_{3}$ dimensions were given higher weightages by TSHDA Officers than that of the $X_{7}, X_{8}, X_{9}, X_{10}$ and $X_{11}$ dimensions, indicating that TSDS are expected to concentrate on these functions by the TSHDA Officers.

The rank assigned by the TRI Extension Officers were also assessed and illustrated in Figure 2. As shown in Figure 2, basically they too have adopted similar ranking pattern except in two cases. TRI Extension officers comparatively assigned higher ranks for X5 dimension than that of the TSHDA Officers assigned and lowest rank for X3 dimension.
Table 3: Test statistics of Friedman test

\begin{tabular}{cc}
\hline Dimensions & $\begin{array}{c}\text { Mean Rank } \\
\text { for Weightages }\end{array}$ \\
\hline $\mathrm{X}_{1}$ & 9.78 \\
$\mathrm{X}_{2}$ & 8.67 \\
$\mathrm{X}_{3}$ & 6.42 \\
$\mathrm{X}_{4}$ & 8.07 \\
$\mathrm{X}_{5}$ & 6.18 \\
$\mathrm{X}_{6}$ & 6.16 \\
$\mathrm{X}_{7}$ & 5.56 \\
$\mathrm{X}_{8}$ & 4.46 \\
$\mathrm{X}_{9}$ & 3.03 \\
$\mathrm{X}_{10}$ & 5.05 \\
$\mathrm{X}_{11}$ & 2.71 \\
\hline
\end{tabular}

Therefore, it is necessary to compare the behaviour of those two groups of Extension workers in assigning the weightages on the 'sensitive', dimensions. In order to test their pattern of assigning, Mann-Whitney u-test was performed, and the following results given in Table 4 were obtained.

There is no significant difference between the two groups when assigning the values for different dimension except only X10 dimension. Therefore, it is safer to assume that both groups (TRI and TSHDA) behave in an almost similar manner. TSHDA, officials have a close link with TSDSs throughout than TRI officials as they are the key service provider of the TSDS. This analysis revealed that related organisational factors have minimum influence on their scoring behaviour. Thus both scores can be pooled for further analysis.

Moreover, respondents' socio personal factors may have an impact on weightages. In order to clarify this fact, the chi-square test was performed to test the association between assigned values and possible socio personal factors. For this analysis rated values and possible independent variables were categorised into two groups and results are given in Table 5. (This test was performed for five personal social factors over eleven dimensions and thus there were fifty-five combinations and the table constructed only for ten combinations, where highest chi-Square values were generated).

Out of the fifty-five combinations, the only significant association was detected between Gender and X5 dimension at the 95\% probability level. Therefore, it is fair to assume that personal social factors have minimal influence on weightages assigned on different dimensions. 


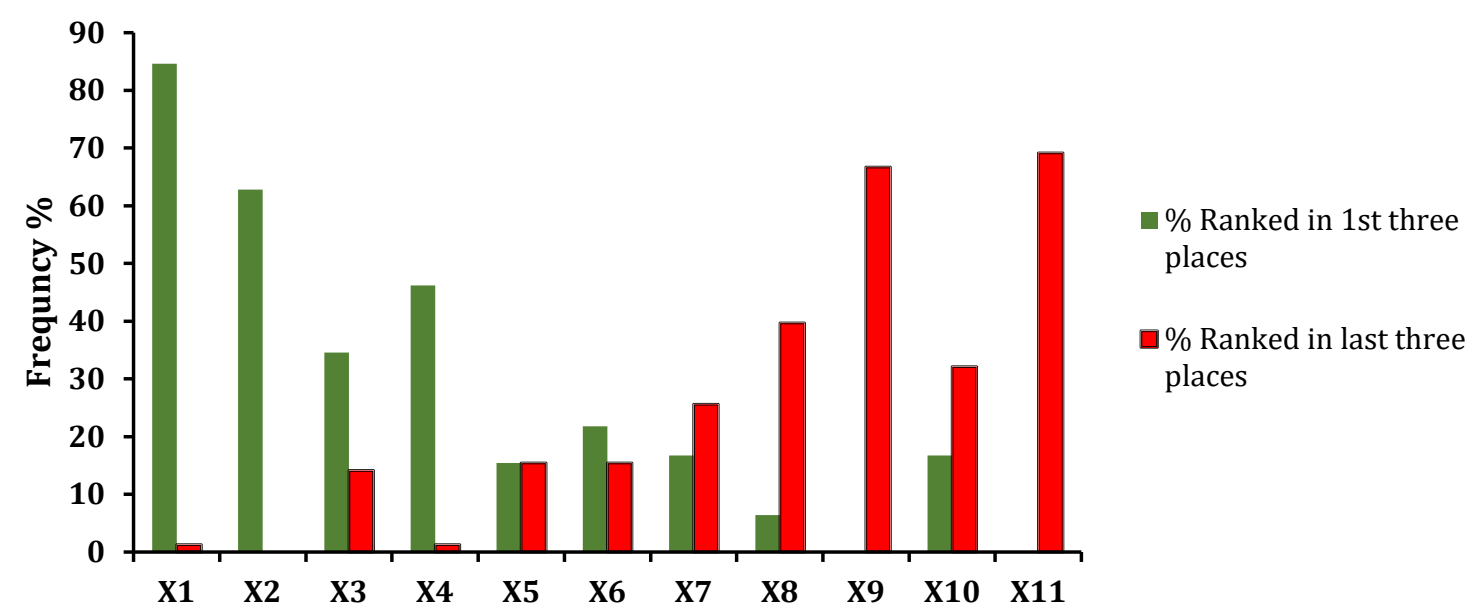

Figure 1: Ranking pattern of Activities by TSHDA extension officers

Before doing a descriptive analysis of the weighted dimensions, observations were plotted using a box plot to identify the outliers in order to take it out from the rest of the analysis. Eleven outliers from eight respondents were identified, and they were removed from the data set, and weighted values of 81 respondents were analysed using descriptive statistics (Table 6).

Therefore, out of the eleven dimensions that were considered, the highest value of 16.31 was estimated for the intervention of the TSDS for Need Identification of the members. The 2 nd and 3rd highest values were estimated for the contribution of TSDSs to the extension activities and dealing with inputs/ resources, respectively. The standard errors of the means for all the estimates are fairly low and 95\% confidence intervals for the estimated means are fairly narrow, - which indicate the low variability among the weighted values. Hence these values could be used to develop a framework to measure the overall efficacy of the TSDSs. However, it is interesting to note that entrepreneurial activities including marketing related activities and For-profit activities are not adequately taken into consideration by the EO ' when formulating their opinions and these two dimensions were received relatively low value (8.35 and 4.49). However, the successful farmer organisations in the world, such as Japanese Agriculture Cooperatives and Indian FPC have more concern about these two factors (Esham and Kobayashi, 2013; Trebbin, 2015). Even a local case study conducted in Morawak Korale Tea Producer Cooperative Society has also revealed that the importance of For-profit and Marketing activities for its success (Mahindapala et al., 2020b). As Mahindapala (2020a) observed, probably this category of extension professionals also of the opinion that these TSDS are still at the primary level and thus they are required to succeed through the 'Production support' than entrepreneurial activities. However, such a perception is not always valid, many Indian FPC have initiated such activities right from the beginning (BIAF, 2011). On the other hand, Indian FPCs were also categorised into three classes based on the stage of their development, and their strategic approaches are different. (Terribian, 2014). Likewise, this scenario may be appropriate for TSDSs, which are operating at a relatively lower scale.

\section{The opinion of the Expert Professionals}

Out of the 25 experts, to whom the questionnaire was sent (electronically), eighteen had responded. Having worked in Universities as Senior academics or as Researchers in research institutes or, in Agribusiness organisations, which have close interactions with TSDS, these participants have the expert knowledge in Extension, Farmer organisations, Agribusiness management. About $72 \%$ of them have PhDs, $17 \%$ have Master's and the rest have a basic degree. Their ranking pattern on the dimensions is summarised in Figure 3. In contrast with the EOs, majority of this category of professionals have ranked 'marketing related activities' $\left(\mathrm{X}_{5}\right)$ either as $1^{\text {st, }} 2^{\text {nd }}$ or $3^{\text {rd }}$ place. It is interesting to observe that none of them has ranked this factor in the last three positions, indicating that these respondents have recognised that the marketing related activities to TSDS are of utmost importance for their development. Further, Figure 4 revealed that dealing with inputs $\left(\mathrm{X}_{4}\right)$ and identification of members needs $\left(\mathrm{X}_{1}\right)$ also recognised as important features by the Experts. According to them, involvement in the nationally important issues $\left(\mathrm{X}_{9}\right)$ and, features related to the organisational administration $\left(\mathrm{X}_{10}\right)$ were the least important dimensions, while the rest of the dimensions have moderate importance to the 


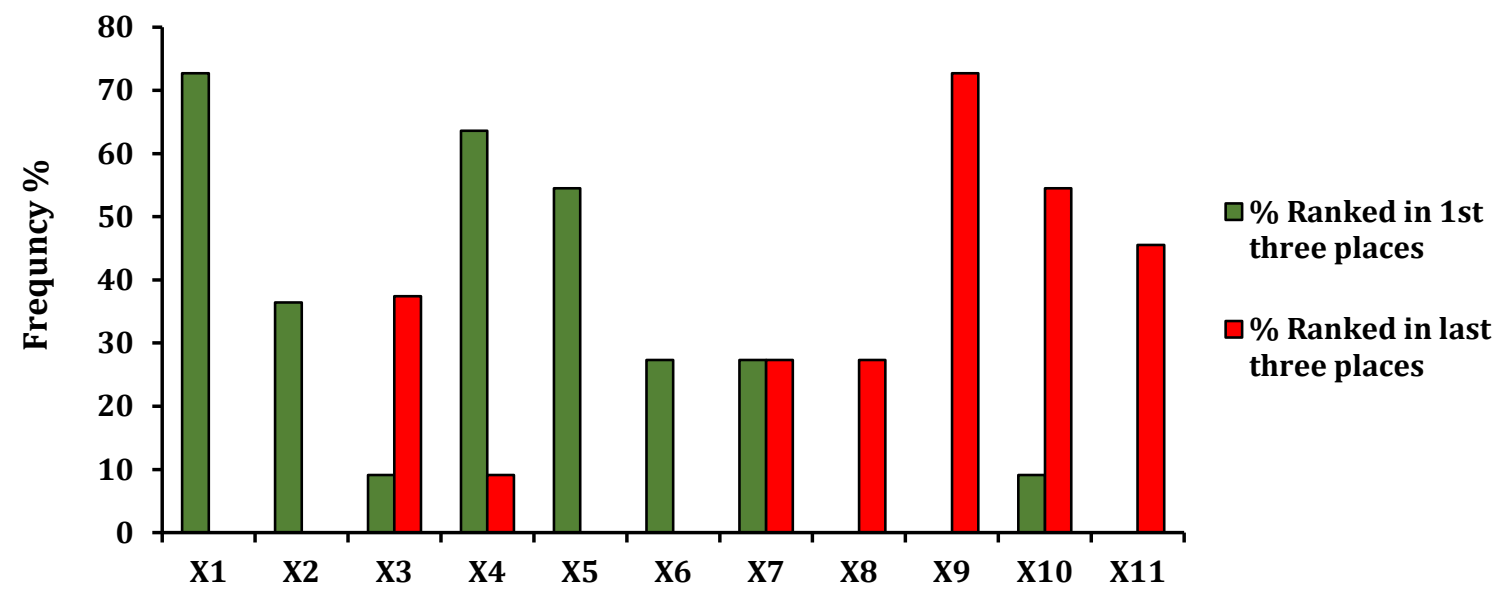

Figure 2: Ranking pattern of TRI extension officers

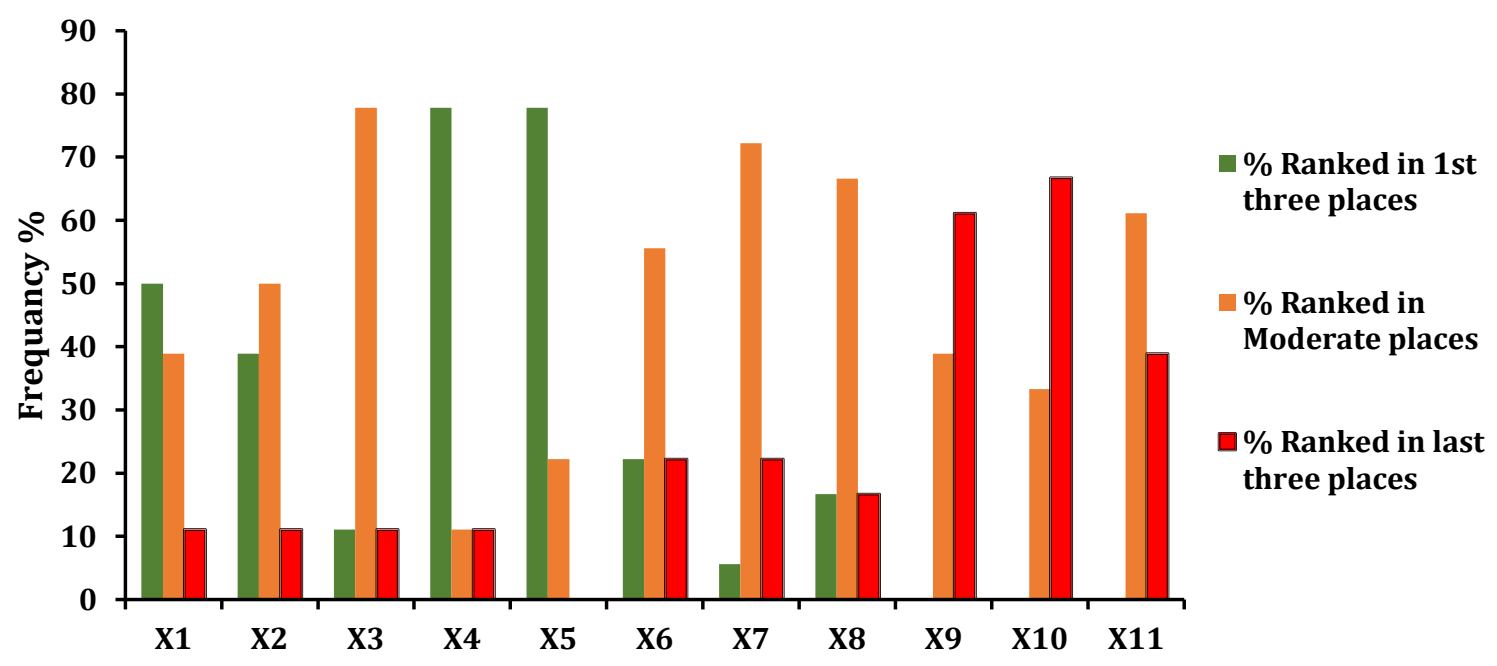

Figure 3: Ranking pattern of the Expert Professionals

Table 4: Test statistics of Mann Whitney test

\begin{tabular}{lcccc}
\hline Dimension & $\begin{array}{c}\text { Mean weightage rank } \\
\text { (TSHDA EOs) }\end{array}$ & $\begin{array}{c}\text { Mean Weightage rank } \\
\text { (TRI EOs) }\end{array}$ & $\begin{array}{c}\text { Mann-Whitney } \\
\text { U-value }\end{array}$ & Significance \\
\hline $\mathrm{X}_{3}$ & 46.34 & 35.56 & 324 & 0.19 \\
$\mathrm{X}_{5}$ & 43.71 & 54.18 & 328 & 0.206 \\
$\mathrm{X}_{9}$ & 46.15 & 36.82 & 339 & 0.257 \\
$\mathrm{X}_{10}$ & 47.4 & 27.95 & 241 & 0.019 \\
$\mathrm{X}_{11}$ & 44.53 & 48.36 & 392 & 0.641 \\
\hline
\end{tabular}


Table 5: Association between weightages and personal socio factors

\begin{tabular}{lcc}
\hline Combination & Pearson Chi-square value & Significance \\
\hline Experience in extension \& $\mathrm{X}_{1}$ & 2.04 & 0.178 \\
Experience in extension \& $\mathrm{X}_{7}$ & 1.72 & 0.178 \\
Experience in TSDS \& $\mathrm{X}_{4}$ & 1.806 & 0.226 \\
Experience in TSDS \& $\mathrm{X}_{5}$ & 1.913 & 0.196 \\
Gender \& $\mathrm{X}_{4}$ & 3.686 & 0.086 \\
Gender \& $\mathrm{X}_{6}$ & 2.093 & 0.195 \\
Job Status \& $\mathrm{X}_{5}$ & 4.328 & 0.049 \\
Job Status \& $\mathrm{X}_{6}$ & 4.18 & 0.058 \\
Education Level \& $\mathrm{X}_{2}$ & 3.569 & 0.096 \\
Education Level \& $\mathrm{X}_{6}$ & 3.558 & 0.109 \\
\hline
\end{tabular}

Table 6: Descriptive statistics for the studied dimensions.

\begin{tabular}{|c|c|c|c|c|c|}
\hline \multirow{2}{*}{ Dimension } & \multirow{2}{*}{ Mean Value } & \multirow{2}{*}{$\begin{array}{l}\text { Std. } \\
\text { Error }\end{array}$} & \multirow{2}{*}{$\begin{array}{c}\text { Std. } \\
\text { Deviation }\end{array}$} & \multicolumn{2}{|c|}{$95 \%$ Confidence Interval of the mean } \\
\hline & & & & Lower & Upper \\
\hline $\mathrm{X}_{1}$ & 16.31 & .607 & 5.465 & 15.1 & 17.52 \\
\hline $\mathrm{X}_{2}$ & 13.54 & .568 & 5.114 & 12.41 & 14.67 \\
\hline $\mathrm{X}_{3}$ & 9.40 & .473 & 4.253 & 8.45 & 10.43 \\
\hline $\mathrm{X}_{4}$ & 11.77 & .430 & 3.871 & 10.91 & 12.62 \\
\hline $\mathrm{X}_{5}$ & 8.35 & .372 & 3.344 & 7.61 & 9.08 \\
\hline $\mathrm{X}_{6}$ & 9.14 & .439 & 3.949 & 8.26 & 10.01 \\
\hline $\mathrm{X}_{7}$ & 7.94 & .367 & 3.303 & 7.21 & 8.67 \\
\hline $\mathrm{X}_{8}$ & 6.60 & .296 & 2.668 & 6.02 & 7.19 \\
\hline $\mathrm{X}_{9}$ & 5.00 & .285 & 2.569 & 4.43 & 5.57 \\
\hline $\mathrm{X}_{10}$ & 7.47 & .423 & 3.811 & 6.63 & 8.31 \\
\hline$X_{11}$ & 4.49 & .256 & 2.303 & 3.98 & 5.00 \\
\hline
\end{tabular}

Table 7: Mean values and other descriptive statistics for the different dimension by Professionals

\begin{tabular}{cccc}
\hline Dimension & Calculated Mean Value & Std. Error & Std. Deviation \\
\hline $\mathrm{X}_{1}$ & 11.82 & 1.25 & 5.18 \\
$\mathrm{X}_{2}$ & 11.41 & 0.88 & 3.61 \\
$\mathrm{X}_{3}$ & 7.59 & .0 .54 & 2.24 \\
$\mathrm{X}_{4}$ & 12.53 & 0.75 & 3.11 \\
$\mathrm{X}_{5}$ & 13.53 & 0.49 & 2.01 \\
$\mathrm{X}_{6}$ & 9.06 & 0.72 & 2.95 \\
$\mathrm{X}_{7}$ & 8.47 & 0.65 & 2.69 \\
$\mathrm{X}_{8}$ & 8.41 & 0.68 & 2.81 \\
$\mathrm{X}_{9}$ & 5.21 & 0.41 & 1.67 \\
$\mathrm{X}_{10}$ & 5.09 & 0.59 & 2.44 \\
$\mathrm{X}_{11}$ & 6.88 & 0.62 & 2.55 \\
\hline
\end{tabular}


TSDS. Moreover, their ranking approach is different from the working EOs; thus showing that their expectations from the TSDS are somewhat different. Their expectations are quantified using the descriptive statistics and given in Table 7 . Therefore, it is clear that Professionals have assigned higher values on dimension related to marketing $\left(\mathrm{X}_{5}\right)$ and, it is in line with some of the belief related to the successful Farmer Organisations in the Asian region (Terabin, 2015) and also compliance to the FAO definition. (Kassam et al., 2011).

\section{Factor analysis}

A Factor Analysis (FA) was also performed to see the possibility of describing those eleven Functions using few uncorrelated 'components. An initial trial was run to see whether the number of observations is sufficient to handle the eleven variables. Since the KMO factor was low (0.3) two variables (X8 and $\mathrm{X} 10)$ were removed based on the communality values and the information generated in the prior analysis. Accordingly, nine variables were subjected to FA and Bartlett's test $(\mathrm{P}<0.0001)$, and KMO factor (0.6) indicated that it is reasonable to go ahead with FA. The varimax rotation has also been done to assure the fair amount of loading only some of the variable with few factors. By examining Eigenvalues $(>1)$, four factors, which accounted for $61 \%$ of the total variance were extracted. The rotated component matrix shows that a fair number of loadings on certain variables (Table 8).

Table 8: Rotated component matrix

\begin{tabular}{ccccc}
\hline \multirow{2}{*}{ Variables } & \multicolumn{4}{c}{ Component } \\
\cline { 2 - 5 } & $\mathbf{1}$ & $\mathbf{2}$ & $\mathbf{3}$ & $\mathbf{4}$ \\
\hline $\mathrm{X}_{1}$ & -.736 & & & \\
$\mathrm{X}_{2}$ & & -.781 & & \\
$\mathrm{X}_{3}$ & & & -.835 & \\
$\mathrm{X}_{4}$ & & & .530 & \\
$\mathrm{X}_{5}$ & .761 & & & \\
$\mathrm{X}_{6}$ & & .764 & & \\
$\mathrm{X}_{7}$ & -.663 & & & \\
$\mathrm{X}_{9}$ & & & & \\
$\mathrm{X}_{11}$ & .659 & & & \\
\hline
\end{tabular}

Note: Loadings $<0.5$ were suppressed

This indicated that Variables Need Identification $\left(\mathrm{X}_{1}\right)$, Marketing related activities $\left(\mathrm{X}_{5}\right)$ Joint field approaches $\left(\mathrm{X}_{7}\right)$ and For-profit activities (X11) belong to one component and Extension $\left(\mathrm{X}_{2}\right)$ and (financial services) $X_{6}$ represent a separate component while Welfare support $\left(\mathrm{X}_{3}\right)$ inputs and resources $\left(\mathrm{X}_{4}\right)$ go with another component.
Therefore, it seems that EOs believe that $\mathrm{X}_{1}, \mathrm{X}_{5} \mathrm{X}_{7}$ and $\mathrm{X}_{11}$ dimensions behave in the same way or works for a same latent property of TSDS and $\mathrm{X}_{2}$ and $\mathrm{X}_{6}$ with different property and $\mathrm{X}_{3}$ and $\mathrm{X}_{4}$ with another property. Although $\mathrm{X}_{5}$ and $\mathrm{X}_{11}$ have similarities, it is difficult to understand how $\mathrm{X}_{7}$ associated with that component. Also, it is hard to find visible similarities between Extension and Financial services. This suggests that it is necessary to be cautious when examining these properties in future studies. Furthermore, FA was performed with respect to the ratings given by the professionals, leaving out the $\mathrm{X}_{8}, \mathrm{X}_{9}$ and $\mathrm{X}_{10}$ for the same reasons and $(\mathrm{KMO}=0.5, \mathrm{P}<0.0001)$ and came up with two components, which explained $62 \%$ of the variability and loadings are given in Table 9.

Table 9: Factor loadings after rotation based on the rating of Professionals.

\begin{tabular}{ccc}
\hline \multirow{2}{*}{ Variables } & \multicolumn{2}{c}{ Component } \\
\cline { 2 - 3 } & \multicolumn{1}{c}{$\mathbf{1}$} \\
\hline $\mathrm{X}_{1}$ & $0-0.931$ & 0.906 \\
$\mathrm{X}_{2}$ & & -0.675 \\
$\mathrm{X}_{3}$ & & 0.820 \\
$\mathrm{X}_{4}$ & & \\
$\mathrm{X}_{5}$ & 0.826 & \\
$\mathrm{X}_{6}$ & 0.715 & -0.509 \\
$\mathrm{X}_{7}$ & & \\
$\mathrm{X}_{11}$ & 0.573 & \\
\hline
\end{tabular}

(Note: Loadings $<0.5$ were suppressed)

Compared to the earlier case, this separation is explainable as these dimensions can be grouped into two meaningful components. The component $1\left(\mathrm{X}_{1}, \mathrm{X}_{5}, \mathrm{X}_{6}\right.$ and $\left.\mathrm{X}_{11}\right)$ represent economic-oriented functions and component 2 is, $\left(\mathrm{X}_{2}, \mathrm{X}_{3}, \mathrm{X}_{4} \& \mathrm{X}_{7}\right)$ service-oriented functions. Thus, one may argue that 'Expert' opinions have a clear basis.

\section{CONCLUSIONS}

The two categories of professionals (extension personnel and professionals) prioritize the tasks that TSDS supposed to perform in two different ways. The TSDSs are expected to be more concentrated on marketing related activities by the professionals, while, working extension officers expect TSDS to concentrate more on need identification of the members and extension activities. However, professionals have not undermined the importance of the 
tasks/dimensions of Need Identification, Extension and, Dealing with Inputs and resources valued by the extension officers. Performing For-profit activities received a better rating from the experts than the other category. Other dimensions received a low rating by both parties. However, welfare activities were preferred more by the extension officers.

These findings can be used to develop a framework to assess the TSDS with the support of some other technique (Need to see the correlation with some performance indicators). However, this should be further validated in field situations before being used for TSDS assessment. Further, assessing the

\section{REFERENCES}

Asante., B.O, Sefa, V.A. and Sarpong, D.B. (2011). Determinants of small-scale farmers' decision to join farmer-based organizations in Ghana, African Journal of Agricultural Research. 6(10), 2273-2279

Barham J. and Chitemi C. (2009). "Collective action initiatives to improve marketing performance: lessons from farmer groups in Tanzania, Food Policy. 34, 53 - 59

BAIF, (2011), Agri-horti-forestry for tribal rehabilitation (online). Available at http://www.baif.org.in/ aspx pages/index.asp [Accessed on 20.01.2020]

Bandula, G.G., Abeywickrama, L.M. and De Zoysa, M. (2016). Tea smallholders' perceptions and experience with tea smallholdings

Millennium Study Government of India Ministry of Agriculture. 24, 38 - 67

Esham, M. (2012). Lessons for Farmer Based Organisations (FBO) in Sri Lanka: Experiences from Agricultural Cooperatives (JA) in Japan. Pp 316-335. In: Karunaratne, H. D (Ed.) A Journey in Harmony Sixty Years of Japan - Sri Lanka Relations. University of Colombo and JAGAAS.

Kassam, L., Subasinghe, R. and Phillips, M. (2011). Aquaculture farmer organizations and cluster management: Concepts and experiences - FAO fisheries and aquaculture technical paper, FAO, Rome. p.90

Kazuhito, Y. (2013). Understand the Japan Agriculture Cooperatives, Politics Economy expert opinions of eighteen individuals may not be sufficient.

\section{ACKNOWLEDGEMENT}

All the respondents from TRI, TSHDA, Universities and other organizations and heads of regional extension divisions at Deniyaya, Kottawa, Passara and Hantane TRI regional station who facilitate for data collection are gratefully acknowledged.

development societies (TSHDS) in Matara district of Sri Lanka, Tropical Agriculture Research and Extension. 19(2), 222-227.

Borhstoem, M. (2013). Effective cooperative governance: A practitioner's perspective. Journal of Co-operative Organization and Management. 1, 49-50.

Chamala, S. and Shingi, P. M. (1997). Establishing and strengthening farmer organizations a reference manual. Daya Publishing House, New Delhi.

Dasgupta, P. (2002). Social capital and economic performance: Analytics Mimeo, University of Cambridge and Beijer International Institute of Ecological Economics, Stockholm.

Datta, S. K. (2004). Cooperatives in agriculture: philosophical and theoretical foundations of cooperatives in State of the Indian Farmer. A

(online). Available at http//nippon.com. [Accessed on 14.01.2020].

Mahindapala, K.G.J.P., Jayathilaka, M.W.A.P, Jayawardane L.N.A.C, Kopiyawattage K.P.P. and De Mel M.P.M. (2020a). Role and Capacity of Tea Societies in the Smallholding Sector in Sri Lanka: An Assessment Based on the Perceptions of Extension Officers. Tropical Agricultural Research. 31(1): 43-55.

Mahindapala, K.G.J.P., Jayathilaka, M.W.A.P, Jayawardane L.N.A.C. (2020b). Role of Agriculture Cooperatives as a Farmer-Based Organization in Sri Lanka: A Case Study in Morawak Korale Tea Producers' Cooperative Society.,A Proceeding of International research Conference of Uwa Wellassa University. 
Mangione, T. W. (1995). Mail Surveys: Improving Quality. Thousand Oaks, CA: Sage.

Matchaya, G.C, (2010), Cooperative patronage: The National Smallholder Farmers' Association of Malawi in Kasungu, Development Southern Africa, 27(3), 397-412.

Matchaya, Greenwell Collins and Perotin Virginie, (2013). The impact of cooperative patronage: The case of National Small Holder Farmers' Association (NASFAM) of Malawi in Kasungu District, Agrekon, 52(2), 75-103.

Obeysekara, K.G.B. (2009). Agriculture extension in the tea smallholding sector in Sri Lanka. pp. 160-181. In: Civayoganadan, C. (Ed.) Proceedings of Agriculture Extension conference, 2009. Sri Lanka Agriculture Extension Association.

Ostrom, E. (2000). Social Capital: a pad or fundamental concept? pp172-214. In: Serageldin, D.I. (Ed.) Social Capital: Multifaceted perspective. World Bank Washington DC.

Penrose-Buckley, C. (2007). Producer organizations: A guide to developing collective rural enterprises. Oxford, UK, Oxfam

Rajarathna, A.R., (2007), Roles and Effectiveness of Agricultural Cooperatives in Japan, with Special Emphasis on Organized Farm Activities, Journal of Developments in Sustainable Agriculture, 2 192-198

Salokhe, S. (2016). Farmers producer organization for effective linkage of small producers with the market, International Journal of Applied Research. 2(10): 142-146

Sharma, V. P. (2007). India's Agrarian Crisis and Smallholder Producers' Participation in New Farm Supply Chain Initiatives: A Case Study of Contract Farming. IIM Working Paper No. 200708-01, Indian Institute of Management, Ahmedabad.

Stockbridge, M., Dorward, A. and Kydd, J. (2003). Farmer organizations for market access. Briefing paper presented at Stakeholders Meeting on Farmer Organisations in Malawi, 18-19 June 2003, Lilongwe, Malawi.

Trebbin, A. and Hassler, M. (2012), Farmers' producer companies in India: A new concept for collective action?, Environment and Planning 44(2):411-427

Trebbin A. (2016) Producer Companies and Modern Retail in India-Current State and Future Potentials of Interaction. In: Rao N., Radhakrishna R, Mishra R. and Kata V. (Ed) Organised Retailing and Agri-Business. India Studies in Business and Economics. Springer, New Delhi. 